症例

\title{
腸管切除を回避したプロテイン $\mathrm{S}$ 欠乏症に起因する門脈血栓症の 1 例
}

\author{
沖縄県立八重山病院一般外科 \\ 川㠃恭兵鍵谷卓司小笠原健太 \\ 滝上隆一山本孝夫尾崎信弘
}

症例は69歳の男性で, 急性発症の腹痛を主訴に当院へ救急搬送された。腹部CTにて 門脈（以下 PV と略）本幹, 上腸間膜静脈（以下 SMV と略）の血栓による完全閉塞を 認め, 一部小腸には造影不良も認められた. 上腸間膜静脈・門脈血栓症 $(\mathrm{SMV} / \mathrm{PV}$ thrombosis：以下SMV/PVT と略）による腸管梗塞と考えられ，試験開腹術および血 栓除去術を行った，術後, 抗凝固療法を行ったところ, 腸管血流は改善し, 血栓は退縮 した。プロテインS（PS）活性が17\%と低下して抢り，プロテインS欠そ症が血栓形成 に寄与したと考えられた，PS欠そ症に起因するSMV/PVTは極めて稀で, 腸管壊死を きたすことから致死率が高いとされている．自験例では早期の血栓除去術により腸管切 除を回避することができ，良好な経過を辿ったと考えられたため報告する.

索引用語 : 門脈血栓症, 先天性プロテイン $\mathrm{S}$ 欠乏症

\section{はじめに}

上腸間膜静脈・門脈血栓症（SMV/PVT）は腸管壊 死により致命的な病態を呈することのある比較的稀な 疾患で，非特異的な症状を呈するため，早期診断・治 療が困難とされている。プロテインS (PS) 欠乏症は $\mathrm{SMV} / \mathrm{PVT}$ を呈した場合の致死率は高いとされる1). 今回, われわれはPS欠乏症に起因すると考えられた $\mathrm{SMV} / \mathrm{PVT}$ に対して早期の血栓除去術を行うことに より腸管切除を回避しえた 1 例を経験したため報告す る.

\section{症例}

患者：69歳, 男性.

主訴：腹部全体の痛み。

既往歴・家族歴：特記すべき事項なし.

現病歴: 来院 $2-3$ 日前からの軽度の腹痛が, 来院 当日から急激に増悪したため, 当院へ救急搬送となっ た. 痛みの性状は鈍い鈍痛, 腹部全体に広がっていた。 過去に同様の症状はない.

来院時現症：身長 $166 \mathrm{~cm}$, 体重55kg，血圧116/90 $\mathrm{mmHg}$, 脈拍 64 回/分, 体温 $37.7^{\circ} \mathrm{C}$, 意識は清明, 苦

2021年 2 月 24 日受付 2021 年 3 月11日採用

〈所属施設住所〉

干907-0002 石垣市真栄里584- 1
悶様顔貌, 腹部は平坦・板状硬, 腹部全体に圧痛, 反 跳痛を認めていた.

血液検査所見 : WBC $13,340 / \mu \mathrm{L}, \mathrm{CRP} 0.8 \mathrm{mg} / \mathrm{dL}$, と炎症反応の軽度上昇を認め, 肝胆道系酵素の上昇を 認めなかった。凝固系検查はPT活性 $87 \%, \mathrm{PT}-\mathrm{INR}$ 1.07, APTT 22.1秒であり, FDP $77 \mu \mathrm{g} / \mathrm{mL}$, D-dimer $27.7 \mu \mathrm{g} / \mathrm{mL}$ と著明に上昇していた. PS活性は $17 \%$ と 低下が認められた（Table 1).

腹部造影CT 所見（Fig. 1a）: SMVからPVにかけ て広範囲の血栓を認め, 門脈本幹で完全閉塞しており, ほとんど血流を認めなかった. SMVの側副血行路は

Table 1 来院時の血液検査結果

\begin{tabular}{cc|cc}
\hline WBC & $13,340 / \mathrm{mm}^{3}$ & T-Bil & $1.6 \mathrm{~g} / \mathrm{dL}$ \\
RBC & $478 \times 10^{4} \mathrm{~mm}^{3}$ & AST & $17 \mathrm{U} / \mathrm{L}$ \\
$\mathrm{Hb}$ & $15.1 \mathrm{~g} / \mathrm{dL}$ & ALT & $14 \mathrm{lU} / \mathrm{L}$ \\
$\mathrm{Hct}$ & $44 \%$ & ALP & $312 \mathrm{mg} / \mathrm{dL}$ \\
Plt & $16.2 \mathrm{~mm}^{3}$ & LDH & $2221 \mathrm{U} / \mathrm{L}$ \\
PT & $87 \%$ & Lactate & $1.1 \mathrm{mmol} / \mathrm{L}$ \\
APTT & $22.1 \mathrm{sec}$ & CPK & $981 \mathrm{U} / \mathrm{L}$ \\
FDP & $422 \mu \mathrm{g} / \mathrm{dL}$ & & \\
D-dimer & $27.7 \mu \mathrm{g} / \mathrm{dL}$ & CRP & $0.8 \mathrm{mg} / \mathrm{dL}$ \\
PS 活性 & $17.40 \%$ & BUN & $13.2 \mathrm{mg} / \mathrm{dL}$ \\
PC 活性 & $80 \%$ & Cre & $0.83 \mathrm{mg} / \mathrm{dL}$ \\
Loops anticoagulant & 陰性 & Na & $140 \mathrm{mEq} / \mathrm{L}$ \\
抗cardiolipin 抗体 & $1 \mathrm{U} / \mathrm{ml}$ & $\mathrm{K}$ & $3.2 \mathrm{mEq} / \mathrm{L}$ \\
\hline
\end{tabular}



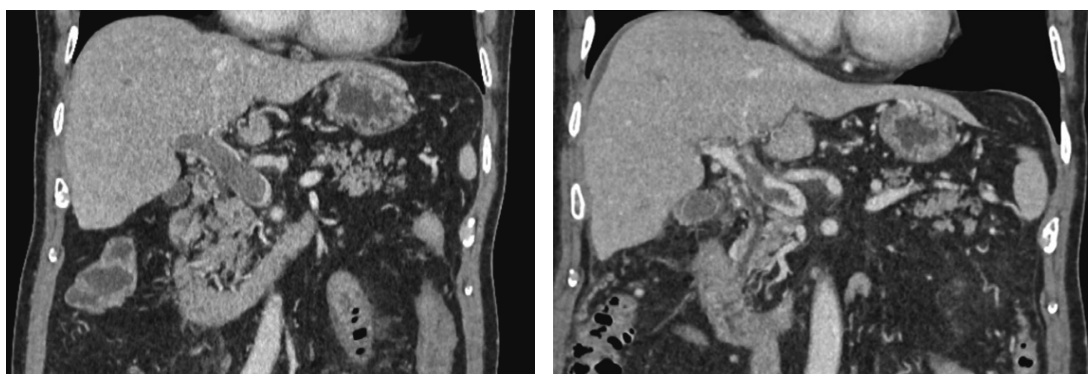

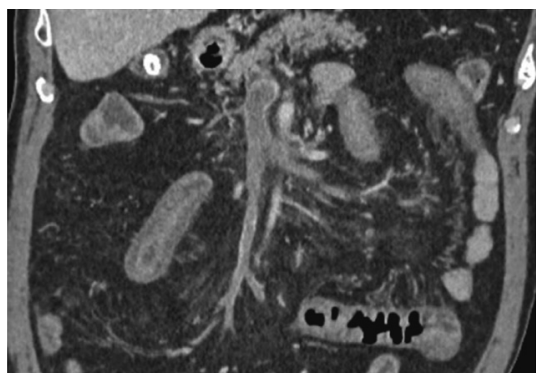

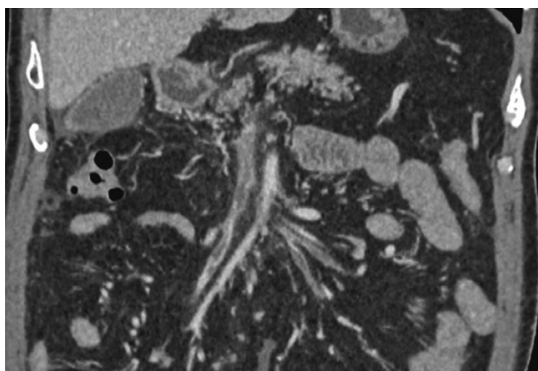

$\mathrm{b}$

Fig. 1a：来院時の造影 CT：門脈本幹から上腸間膜静脈に至るまで血栓閉塞を認め，小腸 の造影不良と浮腫を認める。

b : 凝固療法開始後の造影 CT : 門脈, 上腸間膜静脈内の血流が認められ，血栓は退 縮している. 小腸の浮腫も改善が認められる.

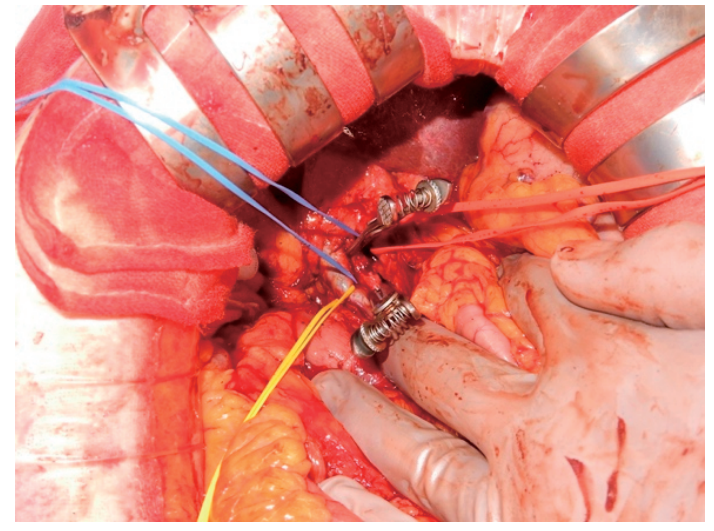

Fig. 2 術中所見 : 固有肝動脈 (赤テープ), 門脈（青テ ープ), 総肝管 (黄色テープ) をそれぞれ確保し, 門脈 を遮断した上で横切開を行い，血栓を除去した。

発達していなかった，小腸の一部は浮腫と造影不良が 認められた。

以上の所見から，急性発症のSMV/PVTによる腸 管虚血および沉発性腹膜炎と診断し, 緊急開腹術を施 行した.

手術所見 (Fig. 2)：上腹部正中切開で開腹した。 小

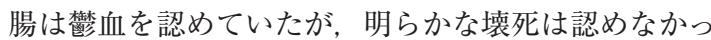
た. 速やかにSMVからPVにかけての血栓除去を行う ために肝十二指腸間膜から固有肝動脈と PV をテーピ ングし，PV本幹を横切開して血栓を除去した。バッ クフローを認めなかったため，肝内門脈とSMVに向 けてFogartyカテーテルを挿入して血栓を除去した. その後バックフローを認めたため, PV を縫合閉鎖し, 手術を終了とした.

病理検査所見：除去された血栓は基質化血栓を認め ず，新鮮血栓であった。

術後経過：術後は未分画へパリンの持続静注による 抗凝固療法を行った。未分画へパリン 500 単位/hで開 始し, APTT50-60秒を目標に適宜調整を行った。腹 部症状に注意しながら，慎重に食事を開始した。経口 摂取後に腹痛の増悪がないことを確認しリバーロキサ バン $30 \mathrm{mg}$ の内服による血栓溶解療法に切り換えた. 術後12日目に撮影した造影CT（Fig. 1b）では血栓は 退縮傾向であり，腹部所見も認められないため退院と なった.リバーロキサバンは $30 \mathrm{mg} を 3$ 週間投与した 後に, $15 \mathrm{mg}$ に変更して内服を継続している．術後 2 カ月経過した現在も再発は認められず，新たな血栓の 形成も認められていない. 

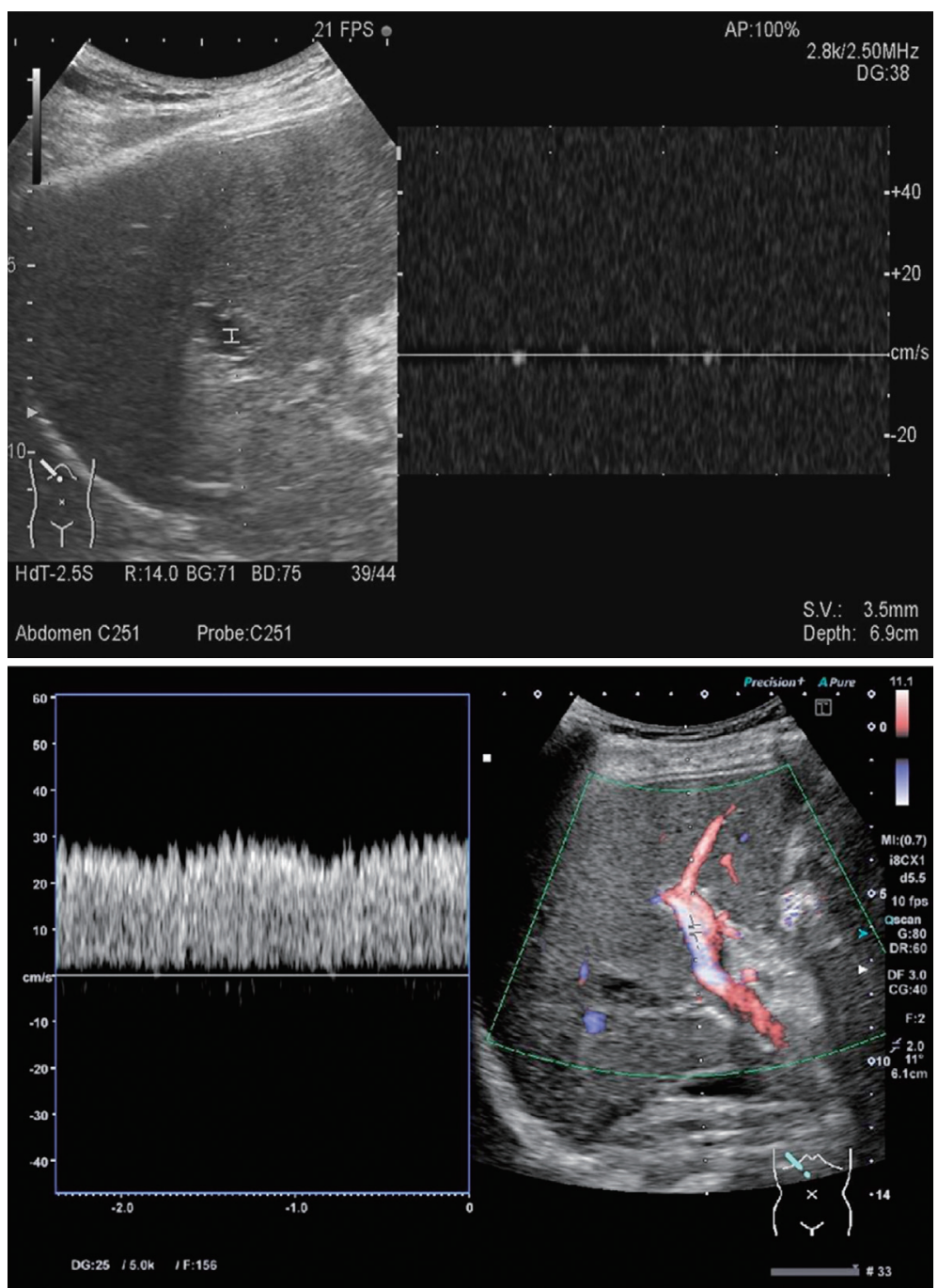

Fig. $3 \mathrm{a}$ 術後 1 日目の腹部超音波 : 門脈内に求肝性の血流を認めなかった.

b 術後 17 日目の腹部超音波 : 門脈内の求肝性の血流が認められ, 血流が改 善している.

術後の腹部超音波 : 術翌日の腹部超音波（Fig. 3a） では門脈本幹の血栓が認められ。求肝性の血流はそし かったが，術後17日目の腹部超音波（Fig. 3b）はPVT を認めるものの退縮しており, PVの求肝性血流は増 強していた.

\section{考察}

$\mathrm{SMV} / \mathrm{PVT}$ は比較的稀な疾患であり, 腸間膜動脈の

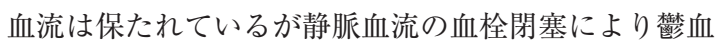
性梗塞から腸管壞死をきたし得る疾患である.SMV/
PVTは, 発症時に特異的な症状がなく早期診断が困 難で，潜在的に病状が進行するとされる1).

$\mathrm{SMV} / \mathrm{PVT}$ の原因となる疾患は様々であり, 小児で は腹腔内感染症に続発するものが約半数で, 他に心奇 形などが報告されている2).成人では門脈圧充進症に 合併したものが最も多いとされ，肝硬変における発生 頻度は $2.86 \%$ と報告されている ${ }^{3)}$. その他に, 肝細胞癌・ 膵癌などの悪性腫瘍の関与, 急性虫垂炎や急性膵炎な どの腹腔内感染症, 真性多血症などの骨䯣増殖性疾患, 
凝固充進状態，外傷，脾摘後などに続発するものが報 告されている ${ }^{4)}$. 自験例は, 中年以降の成人男性に $\mathrm{SMV} / \mathrm{PVT}$ が急性発症し, 続発性の要因として凝固 光進状態であるPS欠乏症が原因と考えられた病態で ある。

PSはビタミン K 依存性糖蛋白質であり, 活性化プ ロテインCが凝固因子である第 Va因子や第 VIII 因子 を不活化する際に補酵素として働くことにより抗凝固 作用を発揮する ${ }^{5)}$. PS欠乏症ではPS 活性が低下する ために抗凝固作用が働かず，血栓形成が立進し血栓症 を発症する．PS欠そ症においてSMV/PVTをきたし た場合の致死率が高いとされている ${ }^{1)}$. PS 久乏症には 先天性と後天性があり, 先天性のPS欠乏症の場合は 常染色体優性の遺伝形式をとる，後天性PS欠乏症の 要因として, 妊娠・エストロゲン製剤・経口抗凝固薬・ 肝疾患・ネフローゼ症候群・血液透析・全身性ループ スエリテマトーデス・敗血症・DIC・ステロイド投与 時・糖尿病が知られている ${ }^{6)}$. 自験例では，いずれの 要因も認められなかったことから先天性PS欠乏症と 診断した. Engesserらの報告7)によれば，先天性PS 欠乏症は若年発症を特徵とし, 最初の血栓症を発症す るのは平均28歳とされる。また，同報告では男性保因 者の血栓症発症率は女性よりも高率であるとされ，家 族性発症の中でも男性家族の発症に留意すべきである と考えられる。自験例では69歳という中年期以降に発 症し，その後の問診では家族性発症は疑われないが, 家系内に保因者を有する可能性があり，今後の慎重な 経過観察が必要と考えられた。

身体所見からSMV/PVTを疑うことは前述のよう に困難であるが，腹部超音波，血管造影検查，造影 CTで診断される場合が多い. 特に造影 CTが有用で あり, $90 \%$ 以上の症例で静脈血栓の存在が指摘可能で 最も有用と報告されている ${ }^{1)}$. 自験例は急性腹症とし て発症し, 早期に造影 CTで診断が可能であった。

SMV/PVTに対する治療には抗血栓療法と外科的 治療がある。

抗血栓療法としてはウロキナーゼや, t-PAなどの 血栓融解療法とヘパリン, ワーファリン, AT- III製剤, 直接経口抗凝固薬のような抗凝固療法が有用であると されている。しかしながら, 抗血栓療法は慢性の経過 で，腸管鬱血や壞死が認められない場合に選択される べきであり，自験例のように側副血行路がなく，明ら かに急性の血栓閉塞と腸管の壊死が疑われる症例に対 しては外科的治療を行うべきである。
外科的治療として, 血栓除去術は側副血行路を損傷 する可能性や術後に血栓が再発する可能性が高いこと から適応は限られているものの，自験例のように血栓 がPVから SMVまで進展し，腸管の頾血が認められ る場合には血栓除去術を考慮するべきである ${ }^{8}$ ．血栓 除去の方法は経門脈アプローチと経上腸間膜静脈経路 が考慮されるが，自験例は可及的速やかにPV内の血 栓を除去するために経門脈アプローチでFogartyカテ ーテルを挿入した.

また，腸管壊死を認めれば，壊死腸管の切除を行っ た上で，吻合せずに second-look-surgeryへ移行する. 二期的手術を行うことで壊死範囲が明確になり，不要 な腸管切除を回避することができる9). 自験例では腸 管の鬱血性梗塞や壊死が生じていない段階で開腹手術 に踏み切り，腸管切除を回避し，血栓除去術のみで治 療することができ，二期的手術も必要としなかったこ とが, 術後の出血を過度に懸念する必要がなく, 迅速 な抗血栓療法へと繋がり，良好な転機を辿ったものと 考えられた．急性期に手術介入を行わなかった場合，

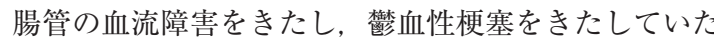
可能性は高いと思われ，急性期に保存的加療が成功し たとしても，入院期間は延長していたと思われる。側 副血行路の発達により腸管の血流障害が改善したとし ても，血栓が慢性化した場合はPVが完全閉塞し，肝 外門脈閉塞症から門脈圧立進症となっていた可能性が 考えられる ${ }^{10)}$ 。この観点からも，本症例のような急性 の広範な SMV/PVTで腸管の血流障害をきたしてい る症例は保存的治療でなく，手術での血栓除去が好ま しいと考えられた。

\section{結語}

PS 欠乏症に起因すると考えられたSMV/PVTの 1 例を経験したため報告した。早期診断には造影 CTが 有用で，腸管壊死を認めない段階で血栓除去術を行う ことにより腸管切除を回避しうる. 早期診断が困難で, 原因疾患の特定を含めて注意すべき病態であるため, 疑われる場合には家族歴の聴取や凝固系の精査を慎重 に行うべきであると考えられた.

利益相反：なし

\section{文 献}

1) Morasch MD, Evaugh JL, Pearce WH, et al: Mesenteric venous thrombosis : a changing clinical entity. J Vasc Surg $2001 ; 34: 680-684$

2) Boles ET Jr, Wise WE Jr, Briken G : Extrahe- 
patic portal hypertension in children. Longterm evaluation. Am J Surg 1986 ; 151 : 734 739

3) Okuda K, Ohnishi K, Kimura K, et al : Incidence of portal vein thrombosis in liver cirrhosis. An angiographic study in 708 patients. Gastroenterology $1985 ; 89$ : $279-286$

4) Ögren M, Bergqvist D, Björck M, et al : Portal vein thrombosis : Prevalence, patient characteristics and lifetime risk : a population study based on 23,796 consecutive autopsies. World J Gastroenterol $2006 ; 12: 2115-2119$

5) Broekmans AW, van Rooyen W, Westerveld BD, et al : Mesenteric vein thrombosis as presenting manifestation of hereditary protein S deficiency.
Gastroenterology 1987 ; 92 : 240-242

6）小林 勲, 浜岡里美: 後天性プロテイン C,プロ テイン S 欠乏症. 臨血 $1992 ; 33: 756-762$

7) Engesser L, Broekmans AW, Briët E, et al : Hereditary protein $\mathrm{S}$ deficiency : clinical manifestations. Ann Intern Med 1987 ; 106 : 677 - 682

8）石川晶久, 伊藤 均, 堀田総一他 : 先天性プロテ イン S欠損症による門脈血栓症の 1 例. 日消誌 $2007 ; 104: 822-828$

9）牧野成人, 河内保之, 清水孝王他：特発性上腸間 膜静脈・門脈血栓症に対し second-look operation を施行した 1 例. 日消外会誌 $2006 ; 39 ： 492-$ 497

10）吉本次郎, 川崎誠治 : 門脈血栓症. 外科 2005 ; $67: 1069-1076$

\title{
A CASE OF PORTAL VEIN THROMBOSIS DUE TO PROTEIN S DEFICIENCY WHICH AVOIDED INTESTINAL RESECTION
}

\author{
Kyohei KAWASAKI, Takuji KAGIYA, Kenta OGASAWARA, \\ Ryuichi TAKIGAMI, Takao YAMAMOTO and Nobuhiro OSAKI \\ Department of General Surgery, Okinawa Yaeyama Hospital
}

A 69-year-old man was admitted to our hospital with acute-onset abdominal pain. Abdominal computed tomography showed complete occlusion of the portal vein (PV) and superior mesenteric vein (SMV) due to thrombus, and poor contrast filling in some of the small intestine. The patient was considered to have an intestinal infarction secondary to SMV/PV thrombosis. Exploratory laparotomy and thrombectomy were performed. Postoperative anticoagulant therapy improved intestinal blood flow and caused thrombus regression. Protein S (PS) activity level was reduced at $17 \%$, suggesting that PS deficiency contributed to the thrombus formation. SMV/PVT caused by PS deficiency is extremely rare and is considered to have a high case fatality rate because it causes intestinal necrosis. In our case, intestinal resection was avoided by early thrombectomy, and the outcome was considered favorable.

Key words : portal vein thrombosis, protein S deficiency 